\title{
The Importance of Fundraising and Endowments: The Role of Private Philanthropy
}

\author{
William G. Tierney
}

\section{Introduction}

Colleges and universities in the United States have a unique component as part of their fiscal resources. Most institutions throughout the world rely on (1) federal and/or state funding and (2) tuition revenue to support their university. Many countries also have largely federal funding for research that supports the institution through indirect costs, as well as off-sets for faculty salaries and laboratories. Funding for research, however, largely impacts only premier research universities, and it plays a significant role in the global reputation of the institution.

Where the United States differs from the vast majority of other countries is with regard to private philanthropy from individuals and private foundations [1]. The United States has three types of fiscal postsecondary institutions: public institutions, private non-profit institutions, and private for-profit institutions. As of 2016, for-profit higher education accounted for approximately $5.4 \%$ of the total undergraduate and $8.9 \%$ of the total graduate student enrollment in the United States and warrants an entirely different conversation that will not be discussed here [2].

Private non-profit colleges and universities were the original beneficiaries of private philanthropy. Indeed, some of the United States premier research universities started through donations of wealthy donors. For example, Leland Stanford, a railroad baron, and his wife started Stanford University in 1885 in honor of their young son who had passed away. Johns Hopkins put aside money in his will for the founding of what became the largest philanthropic bequest in the United States in 1876. Wealthy businessmen donated money to start the University of Southern California in 1880. In the nineteenth century, religious denominations also started small colleges throughout the United States largely to educate students and train individuals for the

W. G. Tierney $(\square)$

University of Southern California, Los Angeles, USA

e-mail:wgtiern@usc.edu ministry. This form of philanthropic giving has largely stopped. Both the University of Notre Dame and Georgetown University, however, are private, Catholic institutions that receive significant revenue from private donations that support the mission of the institution.

In the last 40 years, where private philanthropy has had a significant impact is not simply with private colleges and universities, but also public institutions. The assumption, as recently as 1980, was that a state funded its public colleges and universities, and there was no need for individuals to donate to a public institution in a manner akin to what has been done for private institutions. Indeed, in the 1980s, the first campaign by a public university-Pennsylvania State University-raised $\$ 300$ million, but there was a significant amount of discussion whether a public university should need private donations [3]. Today, such discussions are moot. All public institutions in the United States need additional revenue as federal and state support shrinks [4]. Thus, Harvard University, as a private university, has set the bar for capital campaigns by raising $\$ 9.6$ billion dollars. However, a public institution, the University of Michigan, has raised $\$ 5$ billion [5]. Although the amount of endowment differs from institution to institution, and how much is raised obviously differs, Tables 1 and 2 are illustrative of endowments in higher education [6, 7].

In this paper, I shall outline the strengths and weaknesses of private philanthropy, discuss how one goes about raising money, and how resources are utilized. I also want to point out that private philanthropy is important at any time, but perhaps even more so when a crisis arises such as a pandemic. When federal and state governments have to cut their budgets, and students defer attending the university, institutions need as many alternative sources of funding as possible, and private philanthropy and an endowment is one such revenue stream. Thus, I shall suggest that, in a world of scarce resources where multiple non-profit organizations need public resources, philanthropy provides one additional way for universities to gain additional resources. 
Table 1 Endowment value relative to total annual spending

\begin{tabular}{l|l|l|l}
\hline Institution & Endowment/total spending & Institution & Endowment/total spending \\
\hline Soka & 18.3 & Bowdoin & 7.0 \\
\hline Princeton & 11.6 & Cooper Union & 7.0 \\
\hline Grinnell & 9.9 & Principia & 6.7 \\
\hline Pomona & 9.7 & Wellesley & 6.3 \\
\hline Swarthmore & 9.7 & Notre Dame & 6.3 \\
\hline Amherst & 8.0 & Richmond & 6.1 \\
\hline Washington and Lee & 7.5 & Claremont McKenna & 5.6 \\
\hline Williams & 7.4 & Smith & 5.6 \\
\hline Berea & 7.3 & Stanford & 4.4 \\
\hline Rice & 7.0 & Dartmouth & 4.2 \\
\hline Yale & 7.0 & Massachusetts Institute of Technology & 3.6 \\
\hline Harvard & 7.0 & California Institute of Technology & 0.9 \\
\hline
\end{tabular}

Table 2 Harvard's endowment

\section{How Harvard's Endowment is Currently Spent}

Harvard's Endowment spending for 2018-2019

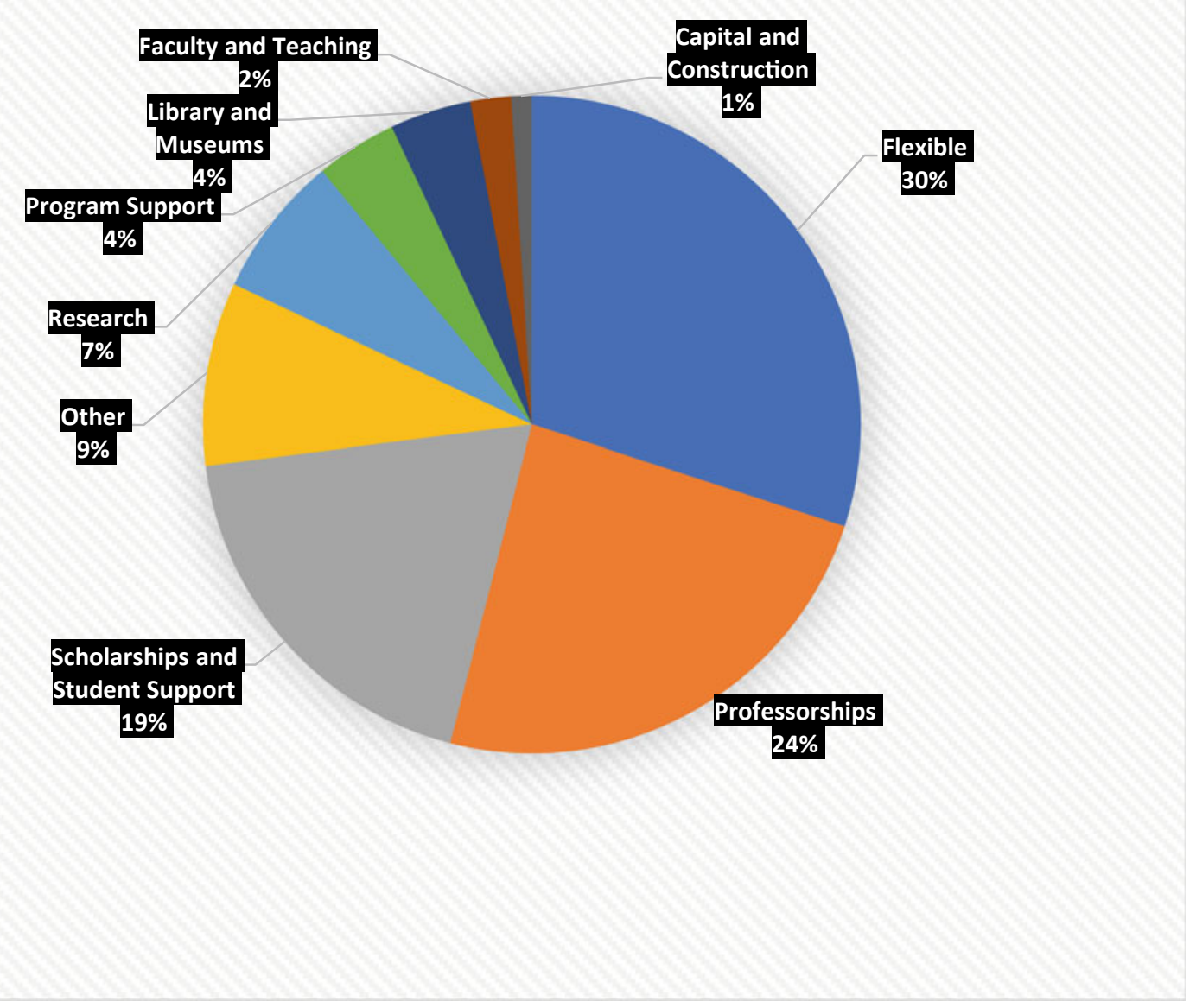




\section{How Philanthropy is Done: Why Would Individuals Donate?}

Any institution that wishes to court donors needs to consider four motivations for those who donate resources to a university.

\subsection{Pay It Forward}

Many individuals who graduate from a university have developed a deep appreciation and affiliation with the institution. There are a great many surveys where adults look back on their lives and say that the best times they had were when they attended their alma mater. A college education may have launched a career, created networks of individuals who became life-long friends, and even helped individuals find a spouse. Insofar as until recently, most of the full-time clientele who attend universities were individuals who were young adults; hence, college was a time when they learned what it meant to be an adult. These alumnae are a primary group of donors for any university.

Many individuals want to maintain contact with their institution, and some will want to repay their institution in some fashion. A donation to a non-profit institution has become a typical way that individuals demonstrate their affection for an organization that made a significant impact on their lives. In essence, the individual is looking backward with fondness and "paying it forward"-giving money that will enable future generations presumably to experience what the donor had when they went to the institution. Such giving can come from individuals who donate a few thousand dollars to individuals who provide multimillion-dollar donations.

\subsection{Make an Impact}

Some individuals have a particular focus that they want to influence. Individuals start foundations or made donations because of a driving interest in a particular issue. Bill and Melinda Gates, for example, started the Gates Foundation with a concern for health and education. Although the foundation has given grants to multiple organizations, one of the primary benefactors of the foundation's largesse has been universities with a focus on health or education.

Similarly, the Keck Foundation started in the 1950s in Los Angeles. William Keck made his money in oil and decided to start a foundation that focused largely on science-based projects in southern California. The foundation has given or raised over $\$ 300$ million dollars in support of the Keck School of Medicine at the University of Southern California.
Other individuals may have fewer resources to make such a significant impact but still want to provide resources to support students or faculty. Someone, for example, may want to endow a chair in Islamic Studies. Someone else may want to support the construction of a swimming pool, and another person may want to offer scholarships to a particular group of students-poor students from a particular ethnic group, for example.

\subsection{Generate a Legacy}

Some individuals want their family name to live in perpetuity. An endowed chair in a particular area of study attached to a person's name suggests that the individual wishes to be remembered for something that is not fleeting. Similarly, a building named in honor of an individual donor on a university campus is a way to establish an institutional memory that will outlive the donor and their immediate family.

Virtually any American campus will have buildings and faculty positions named after an individual. The established tradition also has a generational pull to it. When a friend or colleague makes a donation and puts their name on a building, then other individuals will also want to make a donation so that they too might be memorialized in similar fashion. Many skilled university presidents will encourage potential donors not to make an anonymous gift but instead to give a "naming gift." The assumption is that the donation not only generates revenue for the institution but also will have a cascading impact on additional donors.

\subsection{Create a Tax Benefit}

Philanthropic giving has come with tax benefits in the United States throughout much of the twentieth century. One irony of the world's most capitalist economy is that it has a tax structure that encourages philanthropy. Whether a person makes an individual donation or creates a public foundation or charity for their wealth, the action occurs with considerable tax benefits. In effect, the Internal Revenue Service (IRS) is the grease that encourages philanthropic giving. To be sure, some individuals make donations entirely to accrue a tax benefit. More likely, however, is that the tax structure does not discourage giving as it does in several other countries.

Obviously, when an individual makes a donation to a university, they may do so for multiple reasons. The person may have a particular affection for the institution, want to make an impact in a particular area, and desire to have a legacy that continues once they have died. However, if the person were to be penalized by such giving, then we could expect philanthropic giving to be curtailed. 


\section{The Mechanics of Philanthropy}

Although some individuals invariably write a check and send it to an institution, the vast majority of giving is planned. In the twenty-first century, the norm for planned giving is by way of an annual drive and a capital campaign. Those individuals who are targeted for giving largely fall into three groups: alumnae, potential donors with a particular interest of the institution (e.g. religion, geographic locale, particular specialization of the institution), and new donors.

\subsection{Annual Giving}

Numerous non-profit organizations have an annual giving plan. Although the preferred form of giving is to leave the donation open-ended so the college or university president might spend the money where it is needed most, the norm is to focus annual giving for specific targets, such as scholarships for students. Giving might also focus on a particular part of the institution in which someone has an interest, such as a fitness center or tech lab.

Annual giving used to be confined to a particular time of year-usually in the spring - and American universities had a "phone bank" where undergraduates called alumnae who majored in their discipline. The undergraduate cold-called an alum, spoke glowingly about the institution, and then asked if the individual might make a donation. The technique was not sophisticated, but it had a personal charm that was effective. That simplistic style has morphed into a year-round operation that is a significant component of an institution's development office. The office keeps track of year-to-year donations, the kind of giving that interests the donor, and if the person might be able to increase their donation or know of other individuals who might be new donors.

Clubs have been formed where active alumnae socialize with engaged annual donors to expand the numbers of annual givers. The clubs might be social, have lectures, or are simply parties, but the intent is to bind alumni to the institution and hopefully increase the potential of making a donation. Individuals also might be listed in catalogues the institution provides that counts them as significant members of the academic community. The assumption is that the more recognition an individual receives, the more likely it is that they will continue to make donations and hopefully increase their giving. Moreover, recognition by the institution's president and in annual pronouncements will presumably demonstrate to other potential givers that they should make a donation. In this light, development offices frequently try to ensure that donations have a name attached so that individuals might see who made a contribution. The assumption is that whoever makes a donation not only helps the institution with the contribution, but it also has a ripple effect.

Although alumnae still account for a significant percentage of annual givers, postsecondary institutions also have grown much more sophisticated in their outreach to potential donors who might have an interest in a particular aspect of the institution. Individuals who like American football, for example, may not have graduated from the university, but they have a particular affection for the institution's football team. A university which has a medical school will see many patients who have no affiliation with the institution. They may not care about the university, but they will feel very strongly about the medical unit which operated on them or cured their cancer. The football team and cancer unit also will have annual giving campaigns and generate a great deal of donations from people who are not alumnae.

\subsection{Capital Campaigns}

A capital campaign is a targeted challenge led by the institution's president for a specific amount of money over a set time horizon. There is no major university in the United States that does not engage in a capital campaign. The use of the word "campaign" is purposeful. A capital campaign is not unlike a general waging a non-violent war where victory is when the institution has raised the designated amount of revenue.

Frequently, a new institution's president's primary task is to gear up to develop and carry out a capital campaign. The steps are fivefold: First, the institution develops a strategic plan that sets institutional priorities and gains faculty approval. Second, the infrastructure necessary for a capital campaign has to be gauged. Just as a nation's leader ought not go to war without the requisite troops, a college president has to ensure that the development office is staffed and ready to raise the amount of money that has been set as a goal. Third, the institution's governing board has to actively support and be engaged in the campaign. At most major universities in the United States, the Board of Trustees will be individuals who either "give or get." They may be men and women of significant wealth and will know that during their tenure on the Board they need to make a significant donation that generally is in the millions of dollars. Other individuals may not be wealthy, but they know individuals who have the resources to make a donation, and they will provide entre for the president to court the individuals.

Fourth, a campaign starts quietly so that the president and their staff can "test the waters" in terms of what sorts of donations are likely to garner significant revenue for the university. In effect, the institution wants a "running start." Consequently, if an institution sets a 10-year time horizon to 
raise $\$ 9$ billion (U.S.) dollars, then the actual campaign may begin 2 years prior to the actual kick-off, and they will have hoped to raise close to one billion dollars toward the goal. Successful campaigns may raise the goals and extend the timeframe.

Finally, the actual kickoff to the campaign will be done in a way that tries to generate excitement and enthusiasm. The tenor that wants to be built is that the institution is going to meet its goal; that alumnae should be involved not only out of a sense of obligation, but because it's the right way to give some resources to an organization that engenders confidence; and that ultimately the organization will be stronger. The norm in the United States is that this form of kickoff will come with major announcements of donors who have contributed a few hundred million dollars, and the announcement will be done over a number of months in numerous cities throughout the country. Sometimes, the announcement will also be targeted abroad in cities where the institution has a significant presence (such as London or Shanghai).

Most campaigns reach their goal within the timeframe that has been set, and the president claims success. Just as the start of the campaign garnered celebration and tried to generate news, the conclusion of the campaign does the same. The strategy is not only to have raised a significant amount of revenue, but also to have developed an expanded donor list that will continue to be used for the ongoing annual giving campaign.

\subsection{The Fundraisers}

Undoubtedly, the president of the university is the team leader for fundraising. Institutions that are successful in fundraising have an elaborate organizational arm for a development office headed by a vice president who plans annual giving and capital campaigns. The vice president has a direct line to the President and considerable leeway in terms of primary donors.

The provost and deans of schools or colleges are also important. Whereas the president may spend up to 80 or $90 \%$ of their time on fundraising, it is not uncommon for deans to spend as much as two-thirds of their time on fundraising. Obviously, coordination is essential. A potential donor, for example, may have graduated with a degree in history, but made a billion dollars in information technology and have a passion for movies. The Dean of Humanities argues for the right to speak to an alumnae. The IT Dean believes it is logical that she speaks with the donor, having already known the donor from previous interactions. The Dean of the School of Cinema has Stephen Spielberg on his own board for the School and feels that Spielberg could make a logical request. Unbeknownest to all of them, however, the donor's wife is an art aficionado, and she has already spoken privately to the provost to see if they could endow the School of Art History.

What one wants to avoid is multiple individuals asking for multiple gifts of different sizes at the same time. If the university lacks coordination, then a donor may hesitate to give any money whatsoever. Another donor may simply choose the cheapest option. If a school of humanities costs $\$ 30$ million to endow and a school of cinema costs $\$ 50$ million, then the individual might choose humanities. That's good news for the Dean of Humanities, but the result is that the university has been short-changed $\$ 20$ million. Hence, there's an essential need for coordination, which is normally done by the Vice President for Development's office.

The University also needs to be assiduous in courting new donors. All universities know the names of the world's richest individuals-Bill Gates, Warren Buffett, and the like. The problem is that when everyone knows the same individuals, they are constantly called on to make donations. The successful university is one that finds new donors that no one else knows. Any successful university that fundraises has to depend, in part, on multi-millionaires. Admittedly, there are not an endless number of these individuals, but there are thousands of them. Interestingly, the single greatest factor that accounts for their giving money to a charity or institution has to do with their courtship. Simply stated, if no one courts a donor, then the donor is not likely to part with their money. Individuals, then, are not opposed to making donations, but they need to be courted over time, and a strong relationship needs to develop [8].

One mistake that new fund-raisers often make is to assume that they can simply ask an individual to make a donation, much like undergraduates did a half century ago for the annual campaign. To be sure, some individuals will write a significant check after relatively little involvement with the fundraiser. However, the norm is the opposite. Individuals generally make donations to individuals, not institutions. They may love the institution, but they are ultimately giving money to an individual - the president, dean, and the like - who they believe will be a good steward of the investment. To gain trust of a donor requires a great deal of time, effort, and what many think of as adroit gamesmanship. One needs to meet a donor on their turf. If a donor's preference is to have lunch in New York and the president is in California, then the president needs to go to New York. If a donor wishes to have a pleasant weekend with his wife in California and invites the president, then presumably the weekend is casual, and the president's spouse comes along as well. The result is that it is not uncommon for the president of a major university in the United States to spend 300 nights a year trying to court a long list of donors that the development office has found.

One recent change pertains to the COVID-19 pandemic. Traditionally, fund-raising has been a very personal 
undertaking where individuals meet with one another in an array of formal and informal activities. The pandemic brought that to a halt. A new approach had to be tried, and that approach, especially with a younger generation of philanthropists, is only going to increase in the future. Virtual fundraising where individuals court donors is going to require innovative strategies that, by and large, have not been tested but need to be invented at a time when travel has been made that much more difficult [9].

\subsection{The Forms of Revenue}

The days of someone simply writing a check to the institution are long gone. To be sure, simple donations to a university are still done, but there are also numerous creative ways that individuals make donations. Someone, for example, may write the university into their will, and when they die, the revenue will be made available; however, the honor of naming the gift may occur the moment the individual designates the institution in their will. An individual, for instance, could decide to endow the university's school of business with a gift of $\$ 30$ million dollars. In return, the university names the school in the name of the benefactor. The school becomes the "Smith School of Business." Nevertheless, the $\$ 30$ million-dollar gift does not become available until the individual passes away, which could be in a matter of days or decades.

Other individuals may not even make a gift of money. Instead, they give the university their home, their private art collection, or a villa that they own in a foreign country. A famous author who is an alumna of the university may designate the institution as the repository of their papers. Rather than dollars, someone else may give the university stock options that rise and fall with the market. All of these sorts of gifts count toward the capital campaign, even if the revenue does not become available for years, or even decades. The money also will help the donor in some fashion with regard to their taxable income. The result is thus a "win-win," presumably, for the university and donor. The institution gets revenue; the donor gets a tax break.

\section{How Resources Are Used}

When money arrives at the university, it comes generally in two forms. First, the revenue might be available immediately for the purpose that it has been designated. A donor might wish to endow a building for a school, and the building will be named in their honor. Thus, the "Smith School of Business" could work in "Jones Hall" because the Jones family gave the university $\$ 25$ million dollars to build a building for the business school. Someone else might wish to provide scholarships for the current freshmen class and donate \$5 million dollars toward the effort.

The alternative form of giving is an endowment. A donor endows a school such as the Smith School of Business with a \$20 million-dollar gift. The total gift-when it becomes available - is invested by the university, and the recipient is able to use a percentage of the gift every fiscal year. An individual endows an academic center, for example, with a $\$ 5$ million-dollar gift. The director of the center is able to use $5 \%$ of the endowment every year, or roughly $\$ 250,000$ per year. The endowment is relatively stable revenue that the recipient should be able to count on from year to year. If the money is invested wisely, then the endowment should grow, and, in future years, more income can be utilized. The stock can also crash, and the value of the endowment may shrink. Although the money is obviously smaller than the total gift, an endowment gives the recipient relatively stable funding from year to year, whereas other similar units of the university have to generate revenue every fiscal year.

Although donations can be used for virtually anything a donor desires, in general donors have four interests.

Over the past century, the two most common donations have been for buildings and faculty chairs. Buildings cost a great deal of money and garner a great deal of attention for the donor. The assumption is that a primary piece of the university has attached to it the name of the donor. In a less significant way, but still quite important, are those individuals who attach their names to an endowed chair. Again, the building is a gift where the revenue is used immediately to build the structure, and the endowed chair is able to use $5 \%$ of the revenue toward the salary and other perks for the individual holding the chair.

A third use of donations has to do with the funding of research and associated laboratories. Any individuals who have made their impact in engineering and medicine know how expensive it is to undertake laboratory research. Many donors will make donations aimed at any number of medical problems, such as cancer, diabetes, and heart disease.

A fourth use of the endowment is for scholarships and tuition remission for particular types of students is also common. The challenge of fundraising for tuition remission, however, is that the needs are vast, and it is usually the least desirable form of giving. The tuition at a private or public university in the United States can range from $\$ 50,000$ to $\$ 100,000$. An endowment that covers the costs for students for their entire 4 years would be extraordinary, and it is not something that most donors are particularly fond of funding. Alumni may make contributions toward a fund that helps defray the cost of a small part of an individual's tuition, but, in general, the support is relatively meager.

Finally, the recent pandemic also has caused some institutions to consider using some of the endowment to cover the costs incurred by COVID-19. The problem is that most 
of an endowment's funds are committed to a specific cause (such as scholarships or a building), so one cannot simply shift money to help an institution meet its budget. Some individuals also are against using a long-term endowment to meet short-term needs. Nevertheless, some institutions have reluctantly tapped into their endowments to help them cover their costs.

Presidents particularly like donations to a general fund that allows them to use the revenue however they please, but that is the most difficult money to raise. Donors want to give their money for something that they believe in, for one reason or another. They are less enthused to give their money so that the president might renovate the parking lot, however much the area may need refurbishment.

\section{The Strengths, Weaknesses, and Dangers of Fundraising}

\subsection{Strengths of Fundraising}

The strengths of fund-raising are obvious. Without gifts from benefactors, private universities must rely on tuition. Public institutions require the support of the state/federal government and tuition from students. At a time when parents of students, as well as the students themselves, worry about the cost of tuition, and funding from public entities is in rapid decline, an additional revenue stream is not merely a strength, but a necessity. Indeed, the pandemic has highlighted the fiscal problems that tertiary institutions face. A century ago, no public universities concerned themselves very much with funding other than from the government. Similarly, private universities largely focused on tuition dollars, although many institutions had annual campaigns, and a few had capital campaigns as early as the 1960s, with the first capital campaign being done by Harvard University; they raised $\$ 82$ million, and Chicago, Duke, and Stanford followed with campaigns that exceeded $\$ 100$ million [10].

In the twenty-first century, every college and university, public and private, has some form of fund-raising. More institutions are going out of business today than at any other time in the last century [11]. The primary culprit is a decline in enrollment with the concomitant decline in fiscal resources. Virtually all of the institutions that have closed had modest endowments and fund-raising capability that did not sustain the shortfall in tuition. Similarly, many public universities receive less than $20 \%$ of their total budget from the government. It is impossible to pass off the difference entirely to the customerthe student. The result is a robust approach to fundraising and building endowments. Thus, the strengths of developing fundraising are clear; what we need to consider, however, are the weaknesses and dangers of this form of funding.

\subsection{Weaknesses and Dangers of Fundraising}

Fundraising creates several challenges that do not destroy the advantages to an institution in raising money, but any university president needs to be aware of the dangers before embarking on fund-raising. In particular, there are four challenges.

\subsubsection{Donor Influence}

Any donor who provides an institution with a significant amount of revenue may think that they have the right to particular privileges and to intrude on the internal workings of the institution [12]. At a minimum, if a donor has given $\$ 50$ million dollars to the institution, the donor probably expects that, if they call the president, they will be able to meet with the president immediately. Perhaps they also feel that they should receive special seating at a university event. All of the perks and privileges for a donor is on a continuum which forces the university president and development office to constantly assess what is and is not permissible. Most importantly, donors should have no say in who is admitted, and they should not be able to receive special privileges for their children. Further, a donor should have no say in who gets hired to fill an endowed chair that has been made possible by the monetary resources of the funder. The underlying purpose of an institution has to be that those at the institution are best able to make judgments about academic life based on a meritocratic basis informed by information and knowledge. If donors get to admit or hire whomever they want, then the raison d'etre of the university is brought into question.

\subsubsection{Strategic Direction}

The institution should have a strategic plan in place based on the collective wisdom of the Board of Trustees, the faculty, and the senior administration. The president develops, leads, and implements the plan. Plans should not be so rigid that they are unable to change. Strategic opportunities always exist in an ecological system. However, for one reason or another, not all opportunities should be chosen. When an individual climbs a mountain, there may be many trails that lead to the summit, but the leader of any expedition will choose the one that is best for the team. Similarly, at times, a president will be faced with the difficult decision to reject a potential donation that would strengthen the endowment because it places the institution in a direction that ultimately would be harmful. The danger for any leader is to accept revenue for whatever reason a donor wishes to provide resources. An institution without a strategic direction is one that will ultimately be in jeopardy. The challenge for any institution is to choose a strategic direction, be willing to capitalize on unforeseen opportunities, but also be able to hold fast to its mission. 


\subsubsection{Unforeseen Fiscal Costs}

Related to the first two points are costs that may result from a gift that had not been considered. If a donor provides $\$ 50$ million dollars to build a science building, the costs are generally concerned with construction. What may have not been foreseen is the annual maintenance and upkeep costs of the building that had not been built into the gift. If three generous donors have given the funding necessary for new buildings, the physical plant may have improved dramatically, but the annual costs to the overall budget may be increased by millions of dollars that otherwise would have gone to something else.

Universities also invest their endowment in stocks and bonds. Unfortunately, investments not only go up; the market can go down. A university that has become accustomed to spending the interest on the endowment every year faces difficult decisions when the market falls precipitously, such as during the recession of 2008 and the pandemic of 2020. The point is less that opportunities should be summarily rejected; rather, the institution needs to understand that opportunities come with associated risks.

\subsubsection{Institutional Beliefs}

Any institution has particular beliefs on which it stands. In a religious institution, such as a Catholic university, these beliefs may be self-evident, but they are true to any institution that has a history. Beliefs also change, but they change for a variety of intellectual reasons. A donor who wishes to change the belief system of the institution by way of a significant donation offers a challenge to any organization. Sometimes, it is better for an institution to close than to compromise its values. The purpose of organizational life is not survival at any costs. The work of the president, board, and faculty is to determine and to articulate the beliefs of the institution when a donor's largesse needs to be rejected because it would compromise the institution in a way that would make it unrecognizable.

\section{Conclusions}

I have pointed out here how philanthropic giving has played a significant role in the life of American colleges and universities. On the one hand, donations make options available that otherwise may not have been forthcoming. On the other hand, donations also play a central role in the functioning of the institution as public support declines and tuition increases can no longer be sustained. I described the various forms of fund-raising that takes place - annual giving and capital campaigns - and considered what fund-raising entails. Although I pointed out the obvious strengths of fund-raising, I also cautioned against the fulsome embrace of philanthropy without thinking through the strategic direction of the institution. Regardless of the potential pitfalls that exist, I do not see a decline in the import of philanthropic giving in the foreseeable future, especially given global crises such as the pandemic caused by COVID-19. Accordingly, I see an increase in philanthropic giving throughout the world.

\section{References}

1. N.D. Drezner, Philanthropy and fundraising in American higher education. ASHE Higher Education Report, vol. 37, Number 2 (Jossey Bass, San Francisco, 2011)

2. R. Howarth, L. Stifler, The Failings of Online For-Profit Colleges: Findings from Student Borrower Focus Groups (Brookings Institute, Washington, DC, 2019)

3. W.B. Cook, Fund raising and the college presidency in an era of uncertainty: from 1975 to the present. J. Higher Educ. 68(1), 5386 (1997)

4. M. Mitchell et al., A Lost Decade in Higher Education Funding (Center on Budget and Policy Priorities, Washington, DC, 2017)

5. H. Joslyn, T. Sandoval, The art of the giant campaign. (Chronicle of Philanthropy, 2018), https://www.philanthropy.com/article/ How-HarvardMichigan-Made/244923. Accessed 17 Apr 2020

6. S. Baum, V. Lee, The Role of College and University Endowments (Urban Institute, Washington DC, 2019)

7. A. Hess, Harvard's endowment is worth $\$ 40$ billion-here's how it's spent, www.makeit/CNBC.com. 28 Oct 2019

8. N.D. Drezner, F. Huehls, Fundraising and Institutional Advancement: Theory, Practice, and New Paradigms (Routledge, New York, 2015)

9. P. Fain, Fundraising and h.r. during the crisis. (Inside Higher Ed, 2020), https://www.insidehighered.com/news/2020/03/27/expertsrespond-questions-about-college-fundraising-and-hr-functionsduring-crisis. Accessed 17 Apr 2020

10. T.E. Broce, Fund Raising: The Guide to Raising Money from Private Sources (University of Oklahoma Press, Norman, 1986)

11. J. Colston et al., Anticipating and Managing Precipitous College Closures (New America, Washington, DC, 2020)

12. A. Taylor, Perspectives on the university as a business: the corporate management structure, neoliberalism, and higher education. J. Crit. Educ. Policy Stud. 15(1), 108-109 (2017)

Prof. William G. Tierney is University Professor Emeritus and founding director of the Pullias Center for Higher Education at the University of Southern California. A past president of the Association for the Study of Higher Education (ASHE) and the American Educational Research Association (AERA), He was awarded the Howard R. Bowen Distinguished Career Award from ASHE, and the Distinguished Research Award from Division J of AERA. Tierney is an elected member of the National Academy of Education, a disciplinary society of 200 individuals recognized for their outstanding scholarship and contributions to education, and a Fellow of AERA. He has served as an academic dean at a Native American community college, a Peace Corps volunteer in Morocco, a scholar-in-residence in Malaysia and a Fulbright Scholar in Central America, Australia and India. He has been a Fellow at the Rockefeller Foundation's Center in Bellagio, Italy, and a Fernand Braudel Fellow at the European University Institute in Florence, Italy. His recent books include: Rethinking Education and Poverty; The Impact of Culture on Organizational Decision-making and Higher Education for Democracy: The Role of the University in Civil Society. He earned a master's from Harvard University and a Ph.D. from Stanford University. Professor Tierney is a member of the KAU IAB. 
Open Access This chapter is licensed under the terms of the Creative Commons Attribution 4.0 International License (http://creativecommons. org/licenses/by/4.0/), which permits use, sharing, adaptation, distribution and reproduction in any medium or format, as long as you give appropriate credit to the original author(s) and the source, provide a link to the Creative Commons license and indicate if changes were made.

The images or other third party material in this chapter are included in the chapter's Creative Commons license, unless indicated otherwise in a credit line to the material. If material is not included in the chapter's Creative Commons license and your intended use is not permitted by statutory regulation or exceeds the permitted use, you will need to obtain permission directly from the copyright holder. 